Research Article

\title{
Study on Deep and Large Foundation Pit of a National First-Class Key Tomb Protection Project
}

\author{
Jiagang Zhang $\mathbb{D}^{1}{ }^{1}$ Zhimin Chen $\mathbb{D}^{1},{ }^{1,2}$ Mingzhu $\mathrm{Hu},{ }^{3,4,5}$ and Zhaoguo $\mathrm{Wu}^{6}$ \\ ${ }^{1}$ School of Civil Engineering, Lanzhou Jiaotong University, Lanzhou 730070, China \\ ${ }^{2}$ National and Provincial Joint Engineering Laboratory of Road \& Bridge Disaster Prevention and Control, \\ Lanzhou 730070, China \\ ${ }^{3}$ Northwest Research Institute Co., Ltd. of C.R.E.C, Lanzhou 730000, China \\ ${ }^{4}$ Grottoes and Engineering Application Research on Integration and State Administration of Cultural Heritage \\ of Cultural Relics Protection Key Research Base, Lanzhou 730000, China \\ ${ }^{5}$ Geotechnical Cultural Relics Protection Research Center of Gansu Province, Lanzhou 730000, China \\ ${ }^{6}$ CCCC First Highway Consultants, Xi'an 710075, China \\ Correspondence should be addressed to Zhimin Chen; 0219162@stu.lzjtu.edu.cn
}

Received 13 August 2021; Accepted 28 September 2021; Published 23 November 2021

Academic Editor: Qinghua Zhang

Copyright (C) 2021 Jiagang Zhang et al. This is an open access article distributed under the Creative Commons Attribution License, which permits unrestricted use, distribution, and reproduction in any medium, provided the original work is properly cited.

\begin{abstract}
For the support engineering of the deep and large foundation pit (DLFP) due to tomb protection, there are still no clear standards. The construction of DLFP will introduce large-range transverse and longitudinal disturbance on the stratum; therefore, it should be reinforced. In this paper, the reinforcement of the deep and large foundation pit of a national first-class key tomb protection project is studied. By comparing the existing supporting scheme and the stress conditions of the reinforced tomb, the combination reinforcement scheme by bored pile and pile slab retaining wall is found to be safe and feasible. Furthermore, according to the simulated bending moment, displacement, and axial force of the tomb by numerical analysis, an economic and reasonable mixed anchor support scheme is selected. In order to ensure the stability of the tomb during the supporting process of the foundation pit, a maximum value of $10 \mathrm{~mm}$ for the overall settlement of the tomb can be treated as the control benchmark based on the support and anchorage schemes in each specification and the in-site measured settlement values of the tomb. The determined support, anchorage schemes, and the control benchmark can provide certain technique guidance and research significance for the protection of similar ancient buildings in the future.
\end{abstract}

\section{Introduction}

From the twenty-first century, relative specifications put forward clear requirements on the support effects of the foundation pit and their influence on the surrounding environment, and the conventional design calculation for general foundation pit support is already mature. However, there are still no detailed standards and requirements on the ancient buildings with cultural relics protection value. Besides, the conventional single support type is difficult to meet the design requirements of the foundation pit of ancient tombs, which have complex surrounding environment, strict support effect demand, and large depth and area.
Nowadays, the controlled settlement due to repair of the ancient buildings, ancient tombs, and other cultural heritages protected by the state is mainly based on the experience of experts. The control benchmark of settlement is higher and higher, and some key protection projects even require zero settlement. The increment of the benchmark can better provide the cultural relic from destroying, but it also increases construction difficulty and cost. Wang [1] analyzed the monitoring data of the engineering project of the Line 2 Town God's Temple Station of Ningbo Rail Transit and determined the controlled displacement benchmark, requirement, and detailed protection measurements for protection of the ancient buildings in Town God's Temple, which accumulated experiences for similar projects. 
According to the protection requirements of isolated ancient buildings in soft soil deep foundation pit engineering, Gong et al. [2] simulated various construction conditions of foundation pit excavation by using PLAXIS finite element software and determined the support mode that can effectively control the deformation of isolated ancient buildings. Besides, Wang et al. [3] compared and analyzed the stress distribution of the foundation pit of an ancient building under original and modified design conditions, which can provide information for the dynamic design of the foundation pit. In addition, Qiu et al. [4] made a detailed analysis on the design and construction of a super deep and super large foundation pit near the subway. Yooc et al. [5-13] made conducted many researches and discussions on this area. Chen [14] optimized the supporting system and the reinforcement scheme of the pit bottom through the characteristics of the ancillary structure of the station close to the old City God Temple of the historical building. According to this scheme, the deformation of the old City God Temple has been effectively controlled to ensure the smooth progress of the project. Dan et al. [15] provided a new design theory for the complex foundation pit support of the ancient buildings in the old city site. On the analysis of the foundation pit adjacent to key ancient architectural relics, Wang et al. [16] formulated a monitoring scheme, and the feasibility of this scheme is verified by systematically monitoring the foundation pit supporting structure, buildings, groundwater level around foundation pit, and soil mass.

The Dingtao Han Tomb locates in Dingtao County, and there exits earthen ruins outside the tomb, beside the main tomb. The excavation perimeter of the foundation pit is $149 \mathrm{~m}$ in the north-south direction and $110 \mathrm{~m}$ in the eastwest direction. The burial depth of the tomb is $6 \mathrm{~m}$, and the range is a $22.8 \mathrm{~m} \times 22.8 \mathrm{~m}$ square. The buried depth of the earthen site is $6 \mathrm{~m}$, and the range is a $50 \mathrm{~m} \times 50 \mathrm{~m}$ square, as shown in Figure 1.

In order to ensure the safety of the foundation pit and the site not be damaged during excavation, the proper enclosing structure of the foundation pit and support structure of the earthen ruins should be selected, and the proper water stop curtain should be selected to avoid the damage of the antiquities due to excessive settlement.

\section{Analysis on Foundation Pit Reinforcement of the Ancient Tomb}

Based on the project characteristics and construction conditions, several possible used support schemes are analyzed and compared technically and economically.

The excavation area of the foundation pit is very large, which can reach $16,390 \mathrm{~m}^{2}$, and its depth is $16 \mathrm{~m}$ belonging to the deep foundation pit project. There are cultural relics under special state protection in the foundation pit; their high requirements are imposed on its settlement. Many soil layers with different properties exist in the excavation depth of the foundation pit, especially the $8^{\text {th }}$ layer, which contains a lot of confined water and has a great impact on the tomb.
2.1. Comparison of Foundation Pit Support Schemes of the Ancient Tomb Chamber. The bored pile is selected as the support structure.

The construction of the bored pile as the support structure of the foundation pit is convenient, and its cost is low as the construction is mature. Steel support has the advantages of fast, easy assembly, and repeated use. In order to enhance the support force, prestress can be applied to the steel support in advance. Therefore, the support structure has certain economic efficiency and safety. However, the bored pile cannot form a connected successive wall; thus, the waterproof performance is extremely bad; and the water stop curtain shall be set additionally.

The main body of the support structure adopts a diaphragm wall with steel support. When the diaphragm wall is used for construction, the noise and vibration are both very small, which shows great advantages in urban construction. The wall support has great stiffness and good impervious performance; thus, waterproof cloth is not needed. The diaphragm wall can be used as both an enclosure structure and a part of the main structure. Besides, it occupies a small land area. But it also has some disadvantages, such as the high cost. Besides, the construction site must have mud treatment conditions because improper treatment of waste mud will cause serious environmental pollution. In addition, the commonly occurred tank wall collapse in construction can induce the settlement of the tomb and the earthen ruins, and it can also cause exceeded quantity of concrete, which will increase the engineering cost.

The second scheme has the advantage of low noise and small land occupation; thus, it is suitable for urban construction. However, the studied tomb locates in the wild, which has a wide site and no limitations space, noise, and construction disturbance, indicating that the second scheme has no apparent superiority on the present project, and also its cost is very high. In addition, the waterproof curtain has been set outside the foundation pit, and it is a little redundant in terms of the waterproof if the diaphragm wall is made. Compared with the second scheme, bored cast-inplace pile has the advantages of easy construction, low cost, repeated use for many times, and imposing prestress in advance before construction; thus, it has higher cost performance. Considering various factors, the support structure of the bored cast-in-place pile and internal support is finally determined.

\subsection{Comparison of Supporting Materials for Foundation Pit of} the Ancient Tomb Chamber. In the support system of the deep foundation pit, the support systems can be divided into steel support, reinforced concrete support, and reinforced concrete steel tube mixed support. Among them, the reinforced concrete supporting structure has good integrity, large strength, and small deformation, which can ensure construction safety and reliability. However, its construction technique is more complex than steel support, and the demolition is also relatively difficult, inducing a low material recovery rate. The steel support is the most commonly used structure in foundation pit engineering projects because it is 


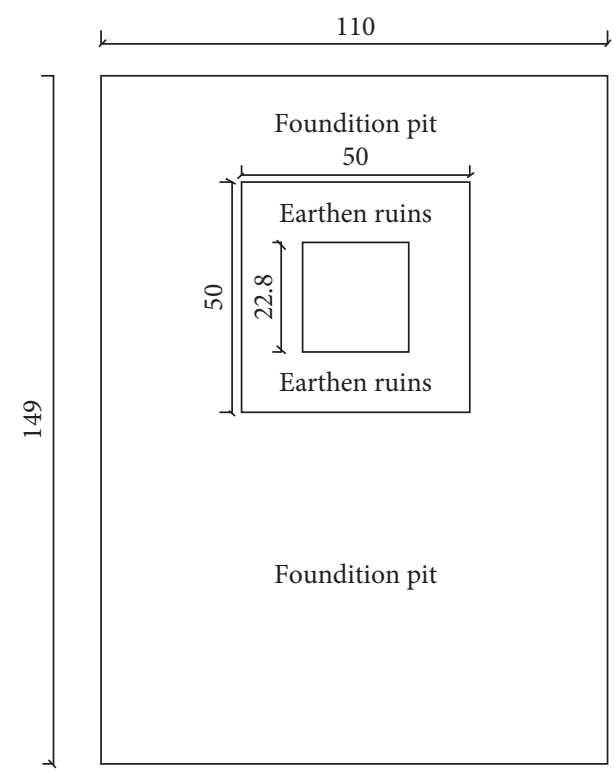

FIGURE 1: Location plan of the ancient tomb.

convenient to be installed and removed. The dosage ratio of steel can improve the support capacity by applying prestress, which can effectively control the deformation of the foundation pit. In the meanwhile, the erection of the steel support is very quick, which can save time and increase the construction efficiency. Besides, the recovery rate of the steel support is high, which can reduce a lot of waste and save cost.

\subsection{Comparison of Reinforcement Schemes of the Ancient} Tomb Room Soil Sites. The earthen ruins belong to the key cultural relics protected by the state; thus, the support structure should have enough strength to protect this structure. Moreover, the construction technology should not only be simple but also fast, and the disturbance to earthen ruins and Han Tombs should be minimal. As the anchor bolt and anchor plate retaining wall have certain damage on the earthen ruins; thus, they can be excluded first. Compared with the pile slab retaining wall, as other retaining walls have no hanging plate, the earthen ruins cannot be protected well. Therefore, combined with the engineering characteristics, existing technologies, economic conditions, and construction period, the pile plate retaining wall is finally selected to strengthen the earth site as shown in Figure 2.

In addition, pile slab retaining wall also has the following obvious advantages: (1) it not only can prevent the overall sliding of the earthen ruins but also can provide well protection because the hanging plate can prevent the local displacement of the earthen ruins; (2) at present, the construction method of the pile plate retaining wall is mature, and the construction team is experienced; therefore, the construction quality and progress can be guaranteed; and (3) the construction of square pile retaining wall has no high requirements on the site conditions; thus, it is convenient to construct, and it has little disturbance to the main body of earthen sites and Han Tombs.

\section{Comparison of Settlement Control Standards}

During the excavation stage of the deep and large foundation pit, there is particularity and high requirements on the protection of the cultural relic architecture. The different standards are shown in Tables 1-3. Therefore, in the design process of the present project, various specifications and reports are referred to, and their deformation control standards and requirements for buildings are preliminarily analyzed. Finally, the deformation control standards of the ancient buildings are determined from the perspective of strict control.

The settlement of the foundation pit can be determined by the soil characteristics, design results, and local experience (Table 2). The soil layer of the tomb is mainly composed of silt, silty clay, and silty sand mixed with silt, and the hydrogeological condition is simple; thus, the soil layer of the tomb is simple. The surrounding tombs are national key protected cultural relics, and the grade of the foundation pit is class I. As the soil layer is simple, the suggested settlement value of the foundation pit is mainly designed based on the grade of the foundation pit and local experience. Besides, the building importance is sensitive to the surrounding environment, the foundation pit of grade 1 adopts the most strict control, and the settlement value is controlled in $10 \mathrm{~mm}$.

\section{Result Analysis of Different Anchor Support Schemes}

The support plan is shown in Table 4 .

4.1. Result Analysis of Mixed Anchor Support Scheme. The earth pressure under various working conditions and in the pile body of bored cast-in-place pile is calculated by using Lizheng system. The calculation results are as follows.

Figure 3 shows the internal force and displacement of the excavation to $6.90 \mathrm{~m}$. After excavation to the depth of $6.90 \mathrm{~m}$, the appearance of the maximum earth pressure locates at $24 \mathrm{~m}$ under the ground, and the pressure value is $500.2 \mathrm{kN} /$ $\mathrm{m}$, while the minimum earth pressure locates at $15 \mathrm{~m}$ under the ground with a value of $0 \mathrm{kN} / \mathrm{m}$. The displacement of the pile top is 0 , and that of the pile bottom is the largest with a value of $4.9 \mathrm{~mm}$. The maximum bending moment is $783.7 \mathrm{kN} \cdot \mathrm{m}$, which appears at about $22 \mathrm{~m}$ under the ground, and the maximum shear stress is $455.3 \mathrm{kN}$, which appears at about $24 \mathrm{~m}$ under the ground.

Figure 4 shows the internal force and displacement after excavation to $6.9 \mathrm{~m}$ with support. After imposing the first bracing, the appearance of the maximum earth pressure locates at $24 \mathrm{~m}$ under the ground, and the pressure value is $500.2 \mathrm{kN} / \mathrm{m}$, while the minimum earth pressure locates at $15 \mathrm{~m}$ under the ground with a value of $0 \mathrm{kN} / \mathrm{m}$. The displacement of the pile top is 0 , and that of the pile bottom is the largest with a value of $4.9 \mathrm{~mm}$. The maximum bending moment is $783.7 \mathrm{kN} \cdot \mathrm{m}$, which appears at about $22 \mathrm{~m}$ under the ground, and the maximum shear stress is $455.3 \mathrm{kN}$, which appears at about $24 \mathrm{~m}$ under the ground. 


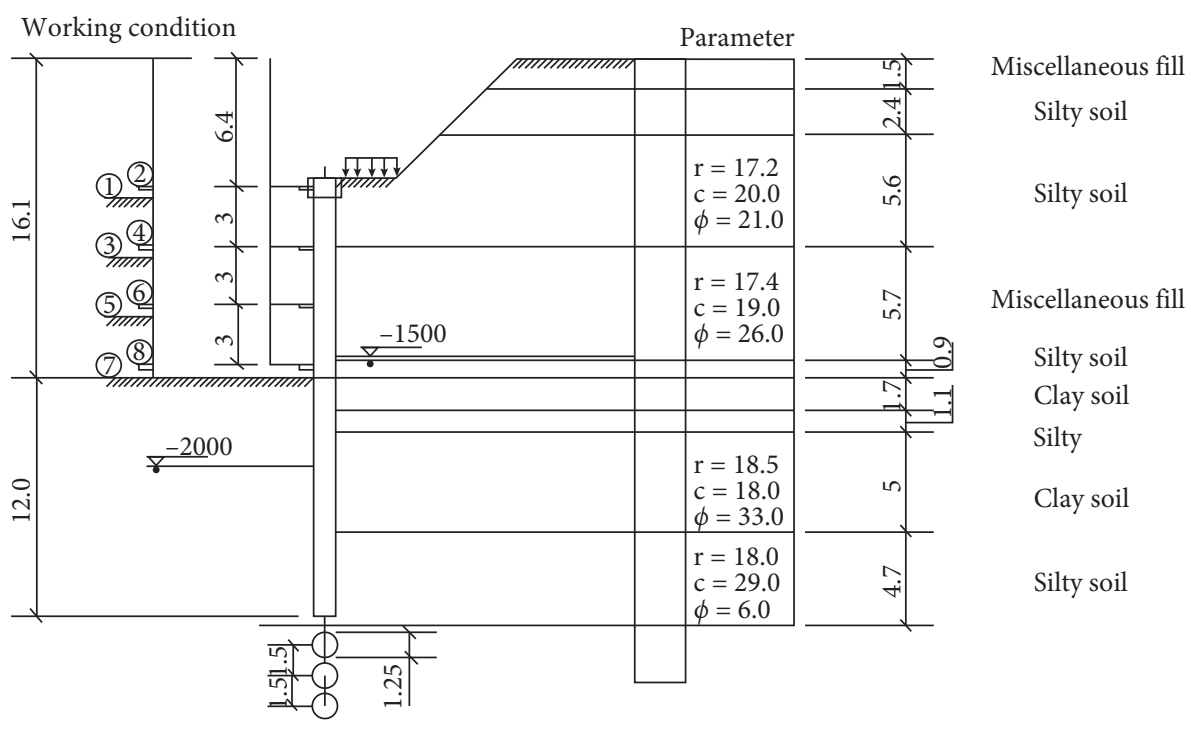

FIgURE 2: Schematic diagram of pile slab retaining wall (unit: $\mathrm{m}$ ).

TABle 1: Comparison of building protection standards.

\begin{tabular}{lcccc}
\hline $\begin{array}{l}\text { Monitoring } \\
\text { items }\end{array}$ & $\begin{array}{c}\text { Building foundation pit } \\
\text { monitoring technical } \\
\text { specifications } \\
\text { (GB50497-2009) }\end{array}$ & $\begin{array}{c}\text { Shanghai standard: code for } \\
\text { construction monitoring of foundation } \\
\text { pit engineering (DG/ } \\
\text { TJ08-2001-2006) }\end{array}$ & $\begin{array}{c}\text { Monitoring alarm value in } \\
\text { report and suggestions on } \\
\text { cultural relics of Jun temple }\end{array}$ & $\begin{array}{c}\text { Recommended } \\
\text { design value }\end{array}$ \\
\hline $\begin{array}{l}\text { Building } \\
\text { settlement }\end{array}$ & Settlement value $10 \sim 60 \mathrm{~mm}$ & $\begin{array}{c}\text { Settlement value, } 10 \sim 60 \mathrm{~mm} \\
\text { Change rate, } 1 \sim 3 \mathrm{~mm} / \mathrm{d}\end{array}$ & $\begin{array}{c}\text { Settlement value, } 15 \mathrm{~mm} \\
\text { Change rate, } 1.5 \mathrm{~mm} / \mathrm{d}\end{array}$ & $\begin{array}{c}\text { Settlement value, } \\
\text { Change rate, } \\
1.5 \mathrm{~mm} / \mathrm{d}\end{array}$ \\
\hline
\end{tabular}

TABLE 2: Settlement values of different foundation pit grades.

\begin{tabular}{ccccc}
\hline \multirow{2}{*}{$\begin{array}{c}\text { Monitoring items } \\
\text { Support structure type }\end{array}$} & I & Foundation pit type & II & III \\
& & Cumulative value $(\mathrm{mm})$ & Cumulative value (mm) & Cumulative value (mm) \\
\hline Settlement around foundation pit & $10 \sim 35$ & $50 \sim 60$ & $60 \sim 80$ \\
\hline
\end{tabular}

TABLe 3: Complexity of soil layer.

$\begin{aligned} & \text { Foundation } \\ & \text { complexity }\end{aligned}$
$\begin{aligned} & \text { Foundation soil properties, degree of weakness, and hydrological conditions } \\ & \text { Complex }\end{aligned}$
$\begin{aligned} & \text { There is large super weak muddy clay within } 2 \mathrm{H} \text { depth; there is silt or sand with large thickness at the bottom of the } \\ & \text { pit, and the water curtain cannot be separated; there is a large area of thick fill and hidden pond distribution; } \\ & \text { hydrogeological conditions: it is adjacent to rivers and has hydraulic connection; the are aquifers with high } \\ & \text { permeability and microconfined water or confined water }\end{aligned}$
$\begin{aligned} & \text { There is mucky cohesive soil or silt within } 2 \mathrm{H} \text { depth; hydrogeological conditions: there is a certain distance from the } \\ & \text { river, and there is no hydraulic connection }\end{aligned}$
$\begin{gathered}\text { The soil property within } 2 \mathrm{H} \text { excavation depth is good; no dark pond distribution; hydrogeological conditions are } \\ \text { simple }\end{gathered}$

Figure 5 shows the internal force and displacement of the excavation to $9.90 \mathrm{~m}$. After excavation to the depth of $9.90 \mathrm{~m}$, the appearance of the maximum earth pressure locates at $24 \mathrm{~m}$ under the ground, and the pressure value is $498.90 \mathrm{kN} /$ $\mathrm{m}$, while the minimum earth pressure locates at $15 \mathrm{~m}$ under the ground with a value of $0 \mathrm{kN} / \mathrm{m}$. The displacement of the pile top is 0 , and that of the pile bottom is the largest with a value of $5.6 \mathrm{~mm}$. The maximum bending moment is $867.8 \mathrm{kN} \cdot \mathrm{m}$, which appears at about $22 \mathrm{~m}$ under the ground, and the maximum shear stress is $478.1 \mathrm{kN}$, which appears at about $24 \mathrm{~m}$ under the ground.

Figure 6 shows the internal force and displacement after excavation to $9.90 \mathrm{~m}$ with support. After imposing the second bracing, the appearance of the maximum earth 
TABLE 4: Different anchor support schemes.

\begin{tabular}{|c|c|c|c|c|c|}
\hline Number & $\begin{array}{l}\text { Working } \\
\text { condition }\end{array}$ & $\begin{array}{l}\text { Depth } \\
\text { (m) }\end{array}$ & Mixed anchor & Reinforced concrete anchor & Steel pipe anchor \\
\hline 1 & Excavation & 6.900 & \multirow{3}{*}{$\begin{array}{l}\text { Internal bracing by reinforced } \\
\text { concrete }\end{array}$} & \multirow{3}{*}{$\begin{array}{l}\text { Internal bracing by reinforced } \\
\text { concrete }\end{array}$} & \multirow{3}{*}{$\begin{array}{l}\text { Inner support by steel } \\
\text { pipe }\end{array}$} \\
\hline 2 & Supporting & 6.400 & & & \\
\hline 3 & Excavation & 9.900 & & & \\
\hline 4 & Supporting & 9.400 & \multirow[t]{2}{*}{ Inner support by steel pipe } & \multirow[t]{2}{*}{$\begin{array}{l}\text { Internal bracing by reinforced } \\
\text { concrete }\end{array}$} & \multirow[t]{2}{*}{$\begin{array}{l}\text { Inner support by steel } \\
\text { pipe }\end{array}$} \\
\hline 5 & Excavation & 12.900 & & & \\
\hline 6 & Supporting & 12.400 & \multirow[t]{2}{*}{ Inner support by steel pipe } & \multirow[t]{2}{*}{$\begin{array}{l}\text { Internal bracing by reinforced } \\
\text { concrete }\end{array}$} & \multirow[t]{2}{*}{$\begin{array}{l}\text { Inner support by steel } \\
\text { pipe }\end{array}$} \\
\hline 7 & Excavation & 15.900 & & & \\
\hline 8 & Supporting & 15.400 & \multirow[t]{2}{*}{ Inner support by steel pipe } & \multirow[t]{2}{*}{$\begin{array}{l}\text { Internal bracing by reinforced } \\
\text { concrete }\end{array}$} & \multirow[t]{2}{*}{$\begin{array}{l}\text { Inner support by steel } \\
\text { pipe }\end{array}$} \\
\hline 9 & Excavation & 16.000 & & & \\
\hline
\end{tabular}
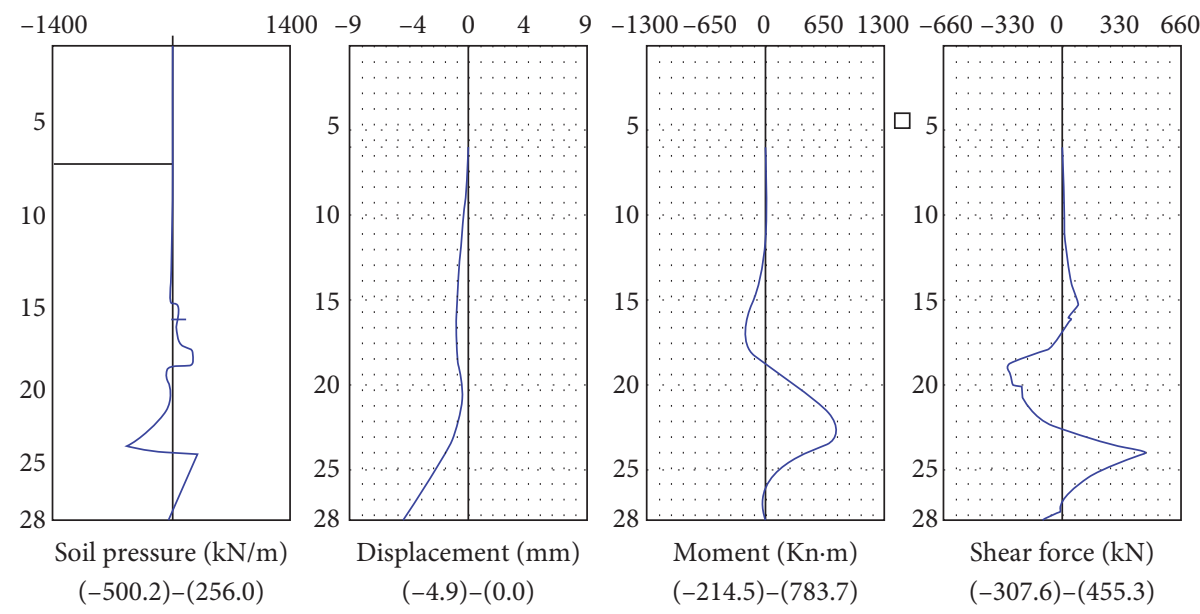

Figure 3: Internal force-displacement diagram of the first bracing.
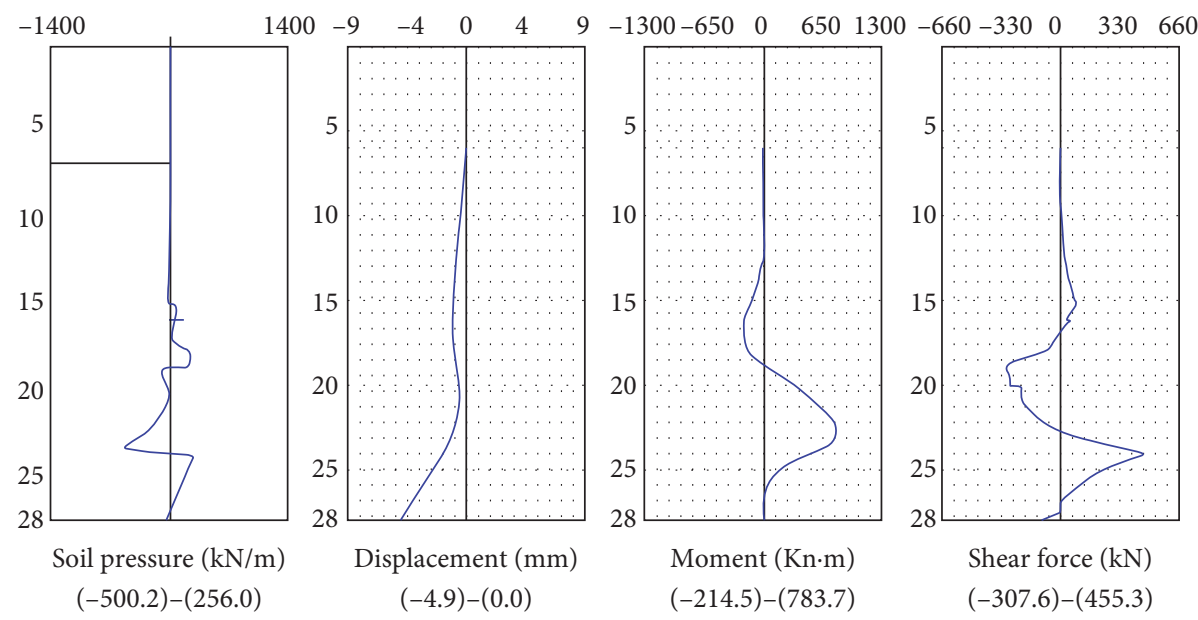

FIGURE 4: Internal force-displacement diagram of the first excavation.

pressure locates at $24 \mathrm{~m}$ under the ground, and the pressure value is $498.9 \mathrm{kN} / \mathrm{m}$, while the minimum earth pressure locates at $15 \mathrm{~m}$ under the ground with a value of $0 \mathrm{kN} / \mathrm{m}$. The displacement of the pile top is 0 , and that of the pile bottom is the largest with a value of $5.6 \mathrm{~mm}$. The maximum bending moment is $867.5 \mathrm{kN} \cdot \mathrm{m}$, which appears at about $22 \mathrm{~m}$ under the ground, and the maximum shear stress is $478.1 \mathrm{kN}$, which appears at about $24 \mathrm{~m}$ under the ground. 

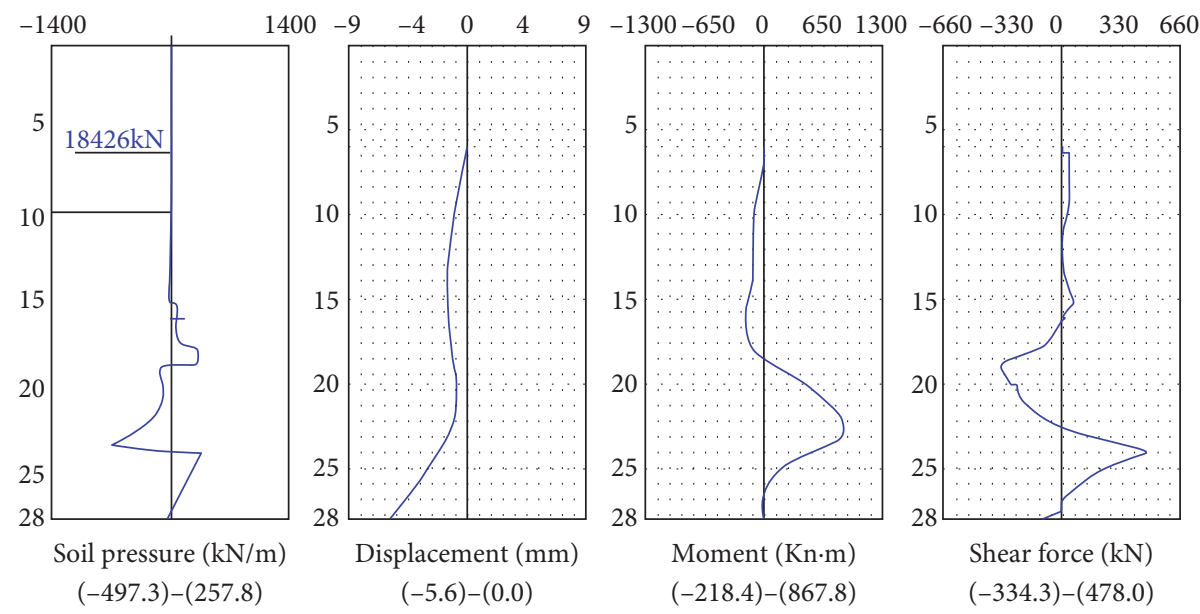

FIGURE 5: Internal force-displacement diagram of the first bracing.
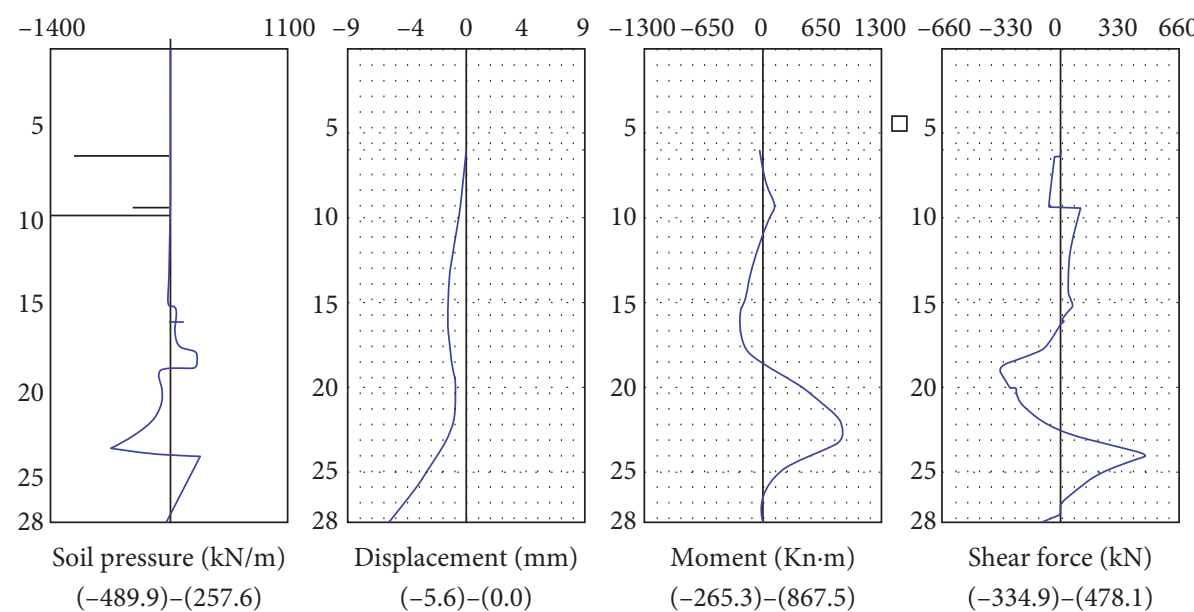

Figure 6: Internal force-displacement diagram of the second excavation.

Figure 7 shows the internal force and displacement of the excavation to $12.90 \mathrm{~m}$. After excavation to the depth of $12.90 \mathrm{~m}$, the appearance of the maximum earth pressure locates at $24 \mathrm{~m}$ under the ground, and the pressure value is $491.6 \mathrm{kN} / \mathrm{m}$, while the minimum earth pressure locates at $10 \mathrm{~m}$ under the ground with a value of $0 \mathrm{kN} / \mathrm{m}$. The displacement of the pile top is 0 , and that of the pile bottom is the largest with a value of $6.6 \mathrm{~mm}$. The maximum bending moment is $1,015.5 \mathrm{kN} \cdot \mathrm{m}$, which appears at about $22 \mathrm{~m}$ under the ground, and the maximum shear stress is $516 \mathrm{kN}$, which appears at about $24 \mathrm{~m}$ under the ground.

Figure 8 shows the internal force and displacement after excavation to $12.90 \mathrm{~m}$ with support. After imposing the third bracing, the appearance of the maximum earth pressure locates at $24 \mathrm{~m}$ under the ground, and the pressure value is $596.7 \mathrm{kN} / \mathrm{m}$, while the minimum earth pressure locates at $10 \mathrm{~m}$ under the ground with a value of $0 \mathrm{kN} / \mathrm{m}$. The displacement of the pile top is 0 , and that of the pile bottom is the largest with a value of $6.6 \mathrm{~mm}$. The maximum bending moment is $995.0 \mathrm{kN} \cdot \mathrm{m}$, which appears at about $22 \mathrm{~m}$ under the ground, and the maximum shear stress is $512.2 \mathrm{kN}$, which appears at about $24 \mathrm{~m}$ under the ground.
Figure 9 shows the internal force and displacement of the excavation to $15.90 \mathrm{~m}$. After excavation to the depth of $15.90 \mathrm{~m}$, the appearance of the maximum earth pressure locates at $24 \mathrm{~m}$ under the ground, and the pressure value is $513.0 \mathrm{kN} / \mathrm{m}$, while the minimum earth pressure locates at $10 \mathrm{~m}$ under the ground with a value of $0 \mathrm{kN} / \mathrm{m}$. The displacement of the pile top is 0 , and that of the pile bottom is the largest with a value of $7.77 \mathrm{~mm}$. The maximum bending moment is $1,198.2 \mathrm{kN} \cdot \mathrm{m}$, which appears at about $22 \mathrm{~m}$ under the ground, and the maximum shear stress is $572.5 \mathrm{kN}$, which appears at about $24 \mathrm{~m}$ under the ground.

Figure 10 shows the internal force and displacement after excavation to $12.90 \mathrm{~m}$ with support. After imposing the forth bracing, the appearance of the maximum earth pressure locates at $24 \mathrm{~m}$ under the ground, and the pressure value is $514.2 \mathrm{kN} / \mathrm{m}$, while the minimum earth pressure locates at $10 \mathrm{~m}$ under the ground with a value of $0 \mathrm{kN} / \mathrm{m}$. The displacement of the pile top is 0 , and that of the pile bottom is the largest with a value of $7.8 \mathrm{~mm}$. The maximum bending moment is $1,169.9 \mathrm{kN} \cdot \mathrm{m}$, which appears at about $22 \mathrm{~m}$ under the ground, and the maximum shear stress is $559.4 \mathrm{kN}$, which appears at about $24 \mathrm{~m}$ under the ground. 


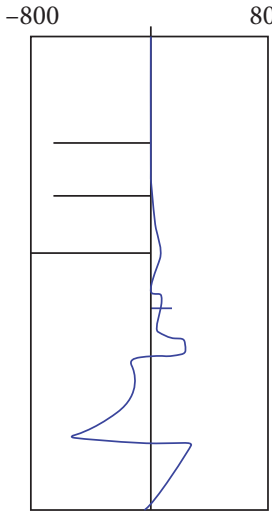

Soil pressure $(\mathrm{kN} / \mathrm{m})$ (-491.6)-(260.7)

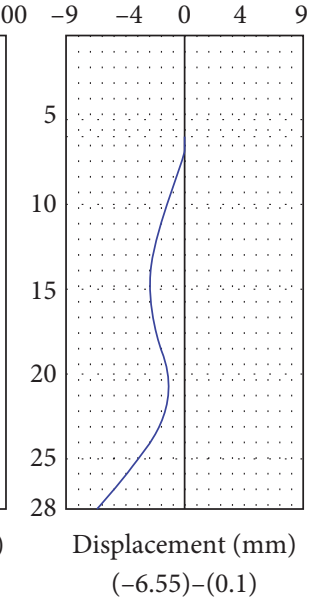

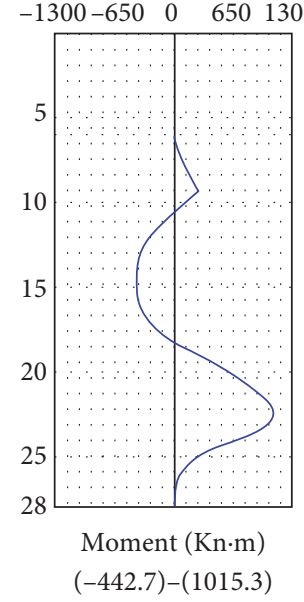

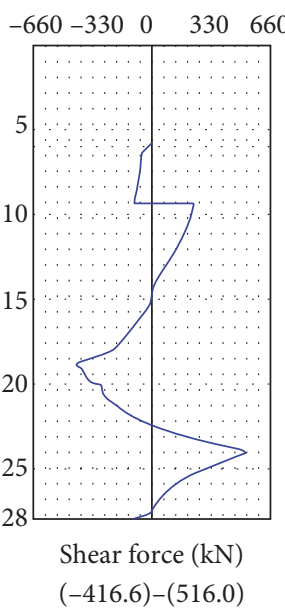

FIGURE 7: Internal force-displacement diagram of the third bracing.
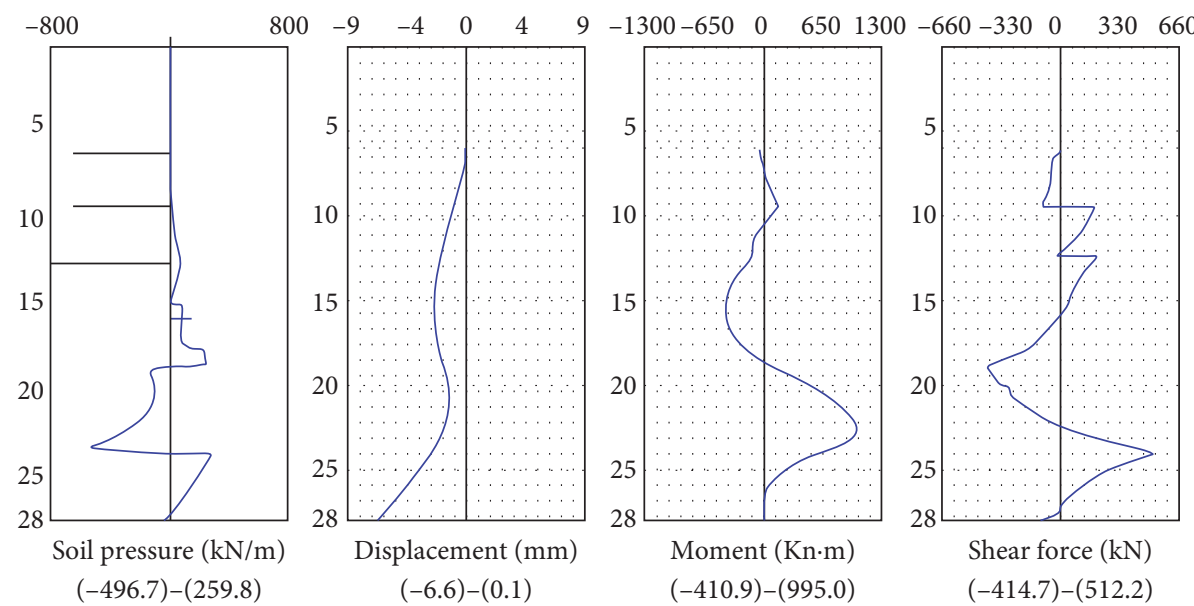

FIGURE 8: Internal force-displacement diagram of the third excavation.
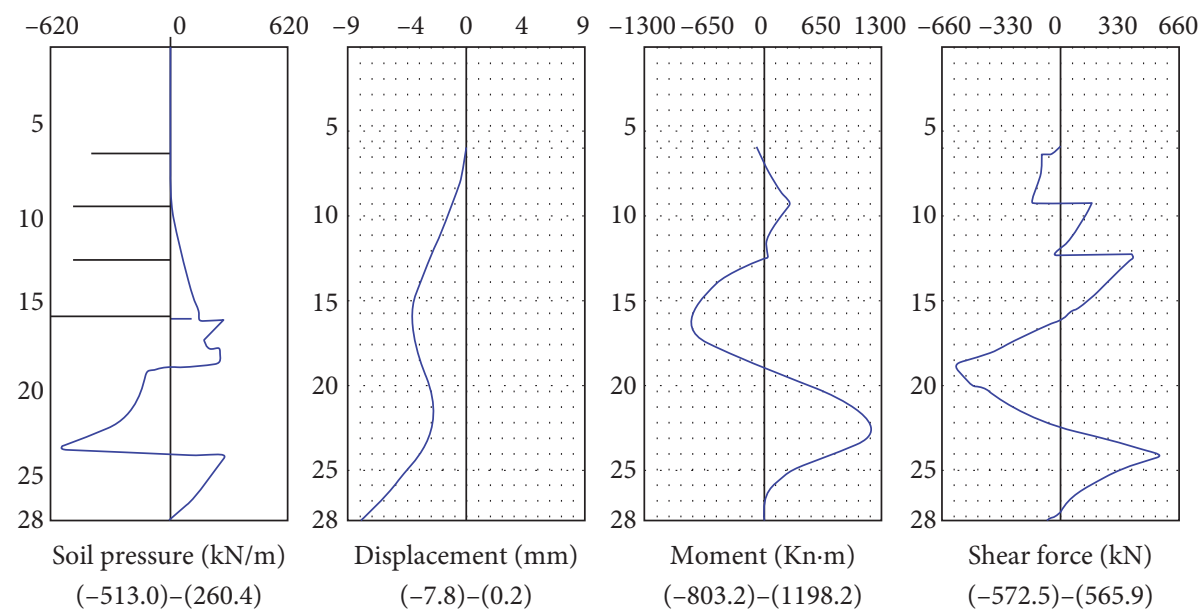

FiguRE 9: Internal force-displacement diagram of the forth bracing.

Figure 11 shows the internal force and displacement of the excavation to $16.00 \mathrm{~m}$. After excavation to the depth of $16.00 \mathrm{~m}$, the appearance of the maximum earth pressure locates at $24 \mathrm{~m}$ under the ground, and the pressure value is $515.9 \mathrm{kN} / \mathrm{m}$, while the minimum earth pressure locates at $10 \mathrm{~m}$ under the ground with a value of $0 \mathrm{kN} / \mathrm{m}$. The 

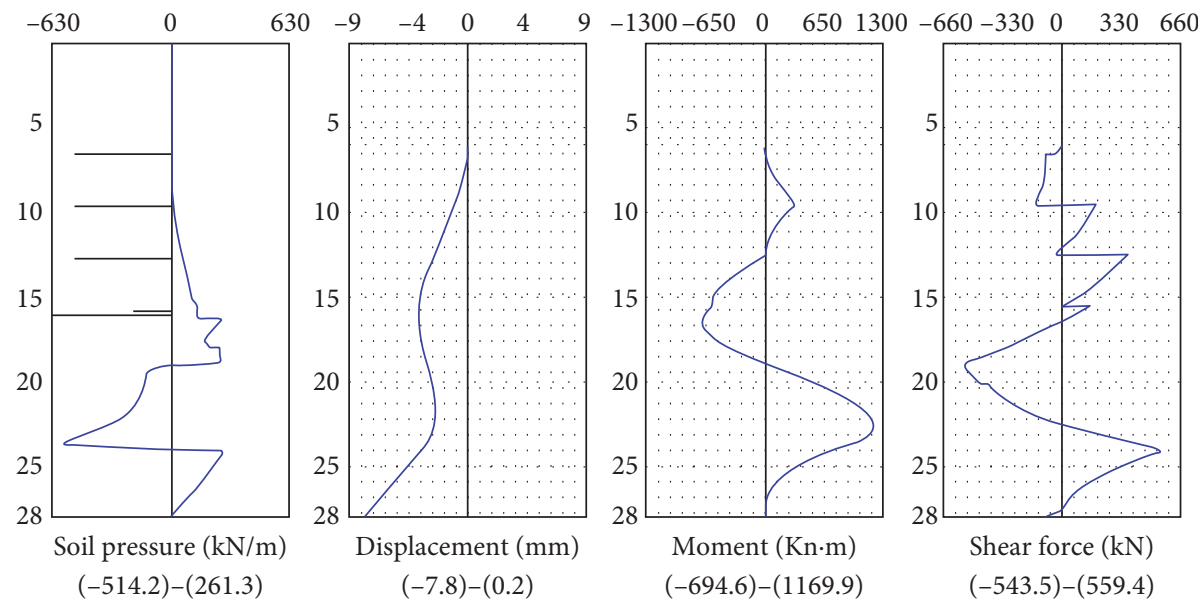

FIgURE 10: Internal force-displacement diagram of the forth excavation.
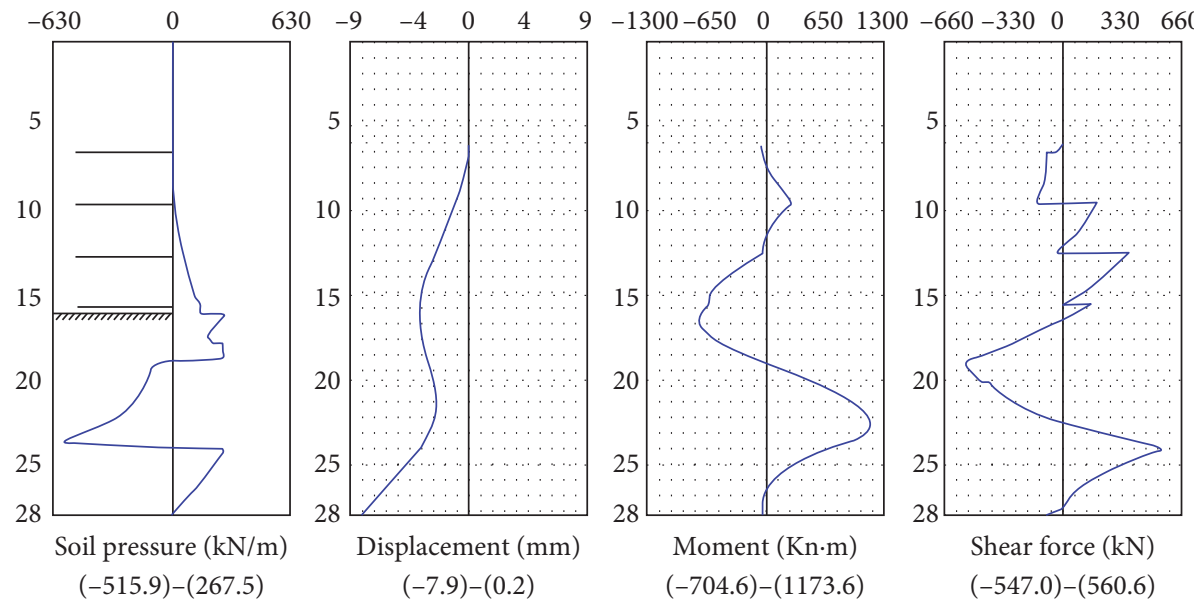

Figure 11: Internal force-displacement diagram of the fifth excavation.

displacement of the pile top is 0 , and that of the pile bottom is the largest with a value of $7.87 \mathrm{~mm}$. The maximum bending moment is $1,173.6 \mathrm{kN} \cdot \mathrm{m}$, which appears at about $22 \mathrm{~m}$ under the ground, and the maximum shear stress is $560.6 \mathrm{kN}$, which appears at about $24 \mathrm{~m}$ under the ground.

The system offers three methods for calculating settlement: triangle method, exponential method, and parabola method. In these methods, the triangle method and exponential method only consider the influence of the lateral displacement area of supporting structure and surface settlement range of retaining structure, but the parabola method also considers the influence of the top and bottom displacements of the supporting structure; therefore, its calculation result is more accurate. Here, the parabola method is adopted for calculating settlement, and the results are plotted in Figure 12.

The settlement of different anchor schemes is shown in Table 5. The maximum settlement is $4 \mathrm{~mm}$, which appears at $6 \mathrm{~m}$ away from the foundation pit, and the minimum influence locates at $20 \mathrm{~m}$ away from the boundary of the foundation pit. Therefore, it can be deemed that there is no settlement at the place with a distance exceeding $20 \mathrm{~m}$.
The settlement value of the mixed anchor scheme and reinforced concrete anchor scheme is $5 \mathrm{~mm}$ at least, but the reinforced concrete anchor scheme is expensive and uneconomical. Therefore, from the perspective of settlement control and economical efficiency, the mixed anchor scheme is the best choice.

\subsection{Results Comparison of Different Anchor Support Schemes.} Figures 13-15 show the comparison of displacement, shear force, and bending moment of different support schemes. Through the comparison of the results of the three schemes, it can be seen that their displacements are close to each other, which are nearly the same, and their bending moments are also similar. For the shear force, the result of scheme 3 is larger than the other two schemes. In total, the support effects of the three schemes have little difference, and they can all ensure the safety of the tomb.

The reinforced concrete support structure has the advantages of good integrity, small displacement, and feasible construction safety. But its construction technology is more complex than steel support, and the demolition is also 


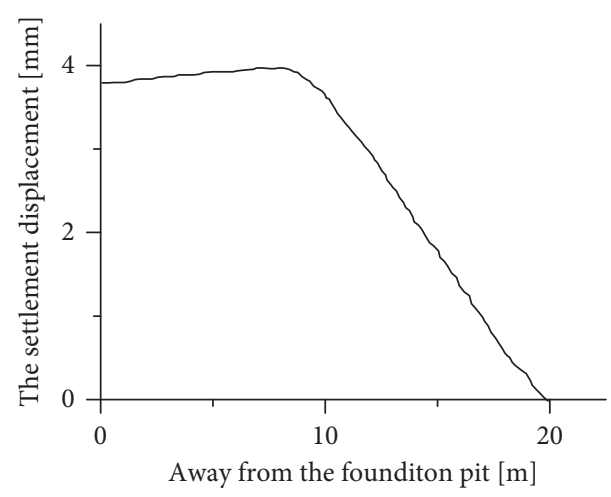

Figure 12: The settlement displacement.

Table 5: Settlement values of different anchor schemes.

\begin{tabular}{lccccc}
\hline & Mixed anchor & $\begin{array}{c}\text { Reinforced concrete } \\
\text { anchor }\end{array}$ & Steel pipe anchor & Double row pile anchor & Required settlement value \\
\hline Settlement value $(\mathrm{mm})$ & 6 & 5 & 8 & 10 & 10 \\
\hline
\end{tabular}

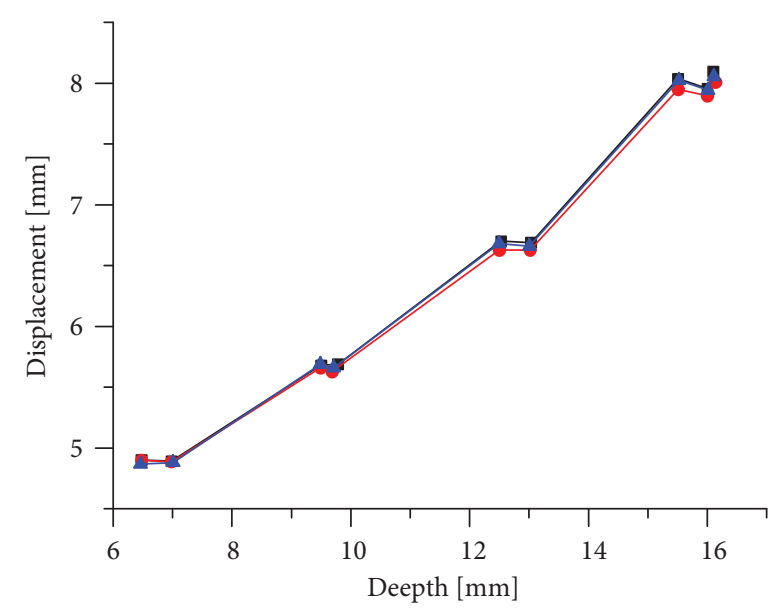

$\rightarrow$ Mixed anchor

$\rightarrow$ Reinforced concrete anchor

$\neg$ Steel pipe anchor

Figure 13: The comparison of displacement.

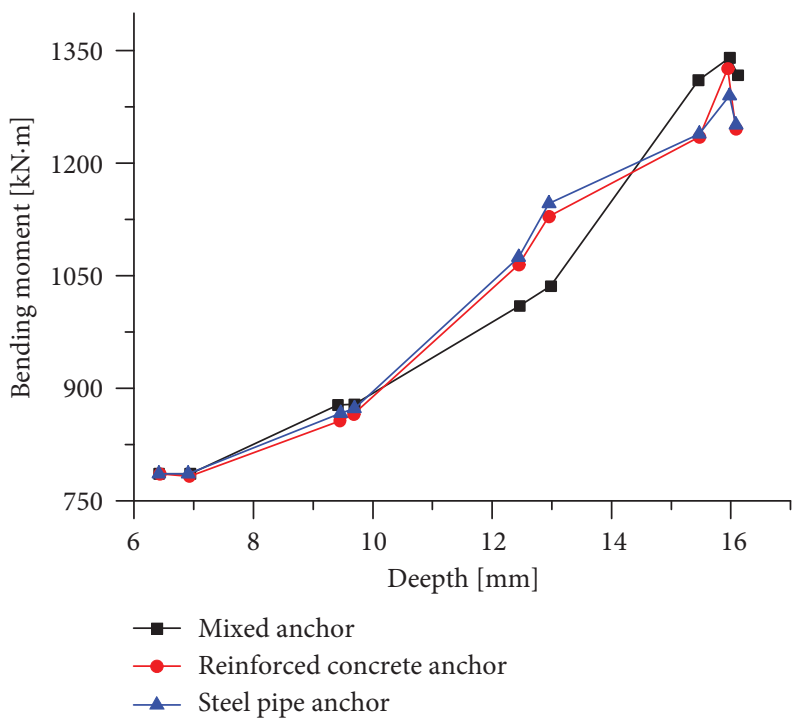

FIgURE 14: The comparison of bending moment. 


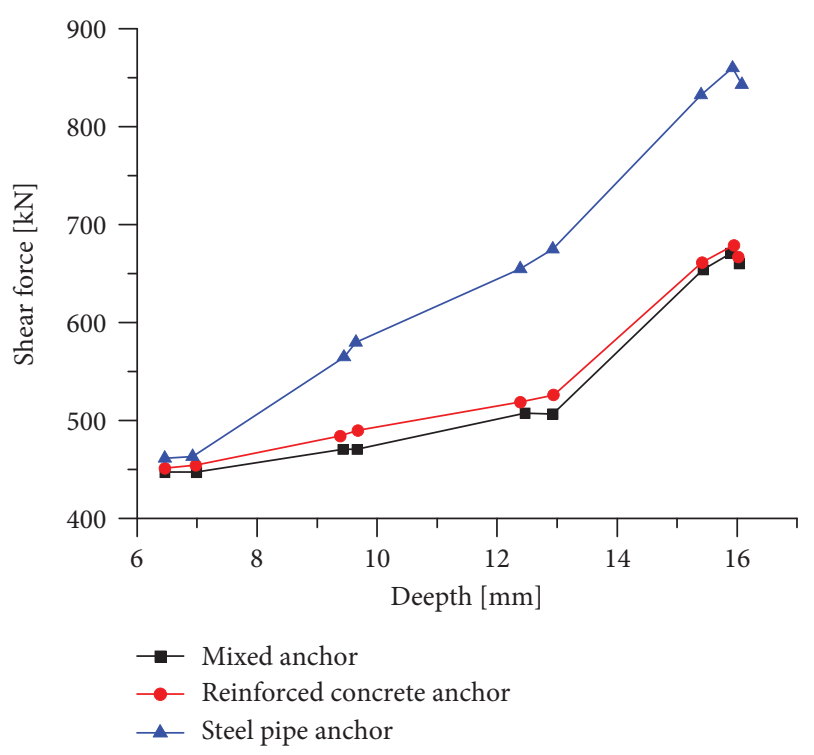

Figure 15: The comparison of shear force.

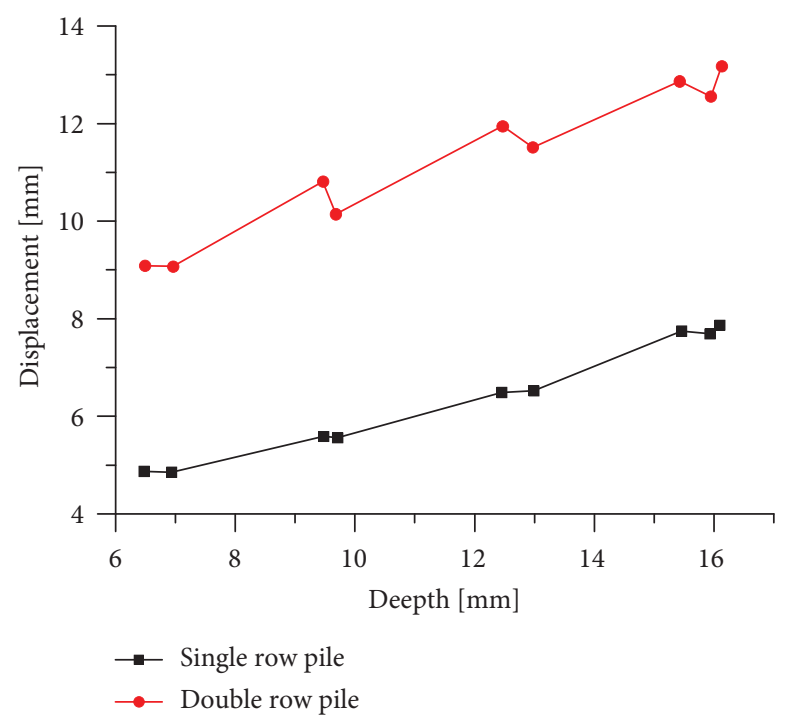

FIgURE 16: The comparison of displacement.

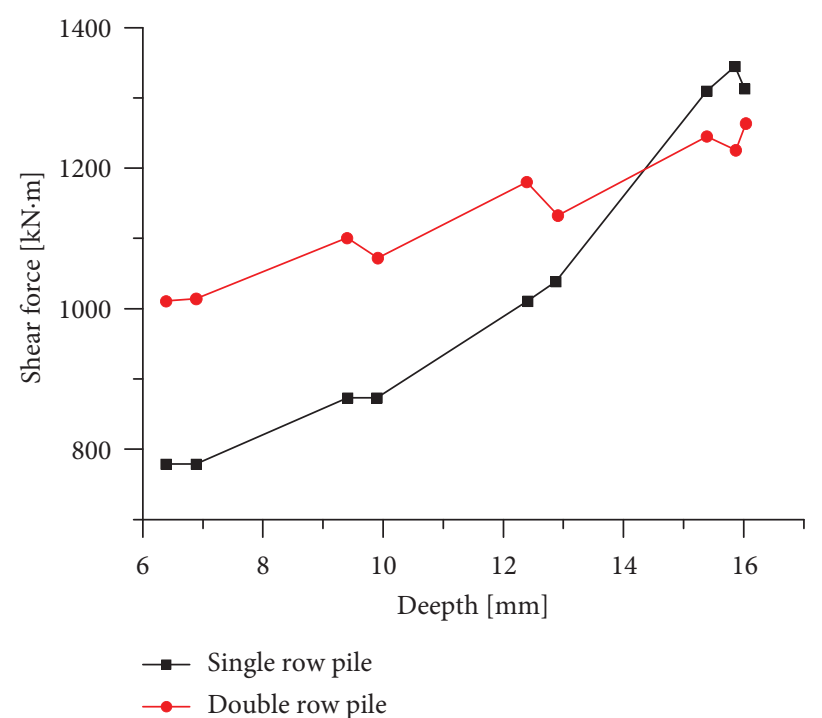

FIgURE 17: The comparison of bending moment. 


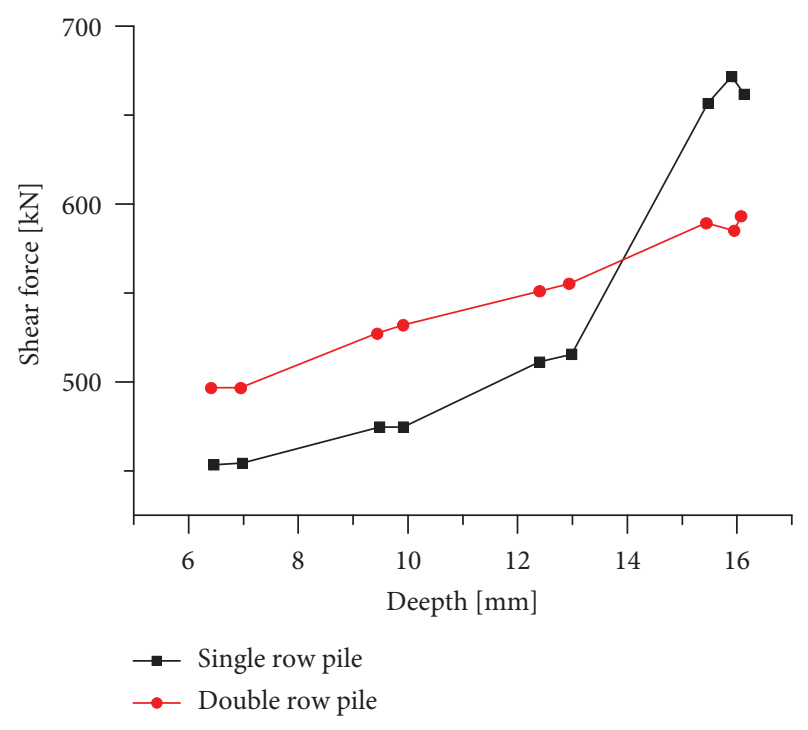

Figure 18: The comparison of shear force.

difficult, which induces a low rate of recovery. Due to the advantages of easy installation and demolition, steel support is most widely used in foundation pit engineering.

According to the above analysis, on the premise of safety and economy, scheme 1 is the most consistent with the project.

4.3. Results Comparison of Different Support Types. The results of adopting double row pile and single row pile are compared as shown in Figures 16-18.

From the comparison of the results of the two-pile row scheme, it can be seen that their displacement and bending moment are quite different, and the results of the doublerow pile are both larger than the single row pile, but their shear forces are similar.

According to the actual situation and economic efficiency, to ensure the safety of the tomb, the first bracing should adopt the reinforced concrete structure, and the $2^{\text {th }}$, $3^{\text {th }}$, and $4^{\text {th }}$ bracing should adopt steel pipe support.

\section{Conclusions}

Take the ancient tomb protection project as the research case, based on the geological conditions and surrounding environment of the foundation pit, along with the requirements of Building Technical Specification of Protection of Foundation Pit (JGJ120 - 2012), the excavation and support scheme of the foundation pit are designed. The following conclusions can be drawn:

(1) The support scheme of the bored cast-in-place pile with internal support and the pile slab retaining wall for tomb reinforcement is most suitable for tomb construction. Compared with the scheme of the underground continuous wall with steel support, the scheme of a bored cast-in-place pile with internal support has the advantages of high efficiency, easy construction, low cost, mature technique, and good stability. Compared with other reinforcement schemes, the pile plate retaining wall has the advantages of the mature technique, convenient construction, and small disturbance to the main body of the tomb, which can effectively prevent the overall sliding of the earth site.

(2) The suggested value of the controlled settlement of the tome is $10 \mathrm{~mm}$. As the soil layer of the tome is simple, it is no need to consider its effect. The more sensitive the building's importance to the surrounding environment, the smaller the controlled value, and the most restrict value is $10 \mathrm{~mm}$.

(3) The displacement of the mixed anchor scheme is the smallest, and its cost is low. By analyzing the results of four schemes, it is found that the displacement of the double row pile anchor scheme is twice of the mixed anchor scheme. The displacement of the reinforced concrete anchor scheme and steel pipe anchor scheme only has little difference. But the reinforced concrete anchor scheme has a high cost, and the steel pipe anchor scheme cannot ensure the safety of the tomb.

(4) The greater the strength of the anchor structure, the smaller the settlement is. The settlement value of the reinforced concrete anchor shall be $5 \mathrm{~mm}$ at least, and that of the mixed anchor shall be $6 \mathrm{~mm}$. However, considering the economic factor, the mixed anchor support scheme is selected [17-25].

\section{Data Availability}

The processed data required to reproduce these findings cannot be shared at this time as the data also form part of an ongoing study.

\section{Conflicts of Interest}

The authors declare no conflicts of interest.

\section{References}

[1] J. Wang, "Analysis of protective effect of foundation pit of metro station on ancient buildings," Construction \& Design for Engineering, vol. 16, no. 7, pp. 62-65+69, 202016.

[2] D. Gong, C. Wu, J. Zeng, and W. Ye, "Example for the protection of isolated island type ancient architecture in soft soil deep foundation pit excavation," Building Structure, vol. 46, no. 8, pp. 95-99, 2016.

[3] X. Wang, B. Zhu, and B. He, "Monitoring and numerical analysis of deep foundation excavation near the ancient architecture," Construction Technology, vol. 43, no. 17, pp. 3942, 2014.

[4] J. Qiu, W. Gao, and Z. Zhou, "Influence analysis and countermeasures for extra-deep foundation pit and extralarge digging piles construction ON adjacent metro," Chinese Journal of Rock Mechanics and Engineering, vol. 31, no. 6, p. 1081, 2013.

[5] C. Yoo, D. Lee, Deep excavation-induced ground surface movement characteristics-a numerical investigation," Computers and Geotechnics, vol. 35, no. 2, pp. 231-252, 2008. 
[6] M. Son, E. J. Cording, Estimation of building damage due to excavation-induced ground movements," Journal of Geotechnical and Geoenvironmental Engineering, vol. 131, no. 2, pp. 162-177, 2005.

[7] C. F. Wu and C. H. Li, "Filed test studies on internal force of pile in pile-anchor supporting system for deep foundation pit," Construction Technology, vol. 383-390, pp. 7713-7717, 2012.

[8] M. A. Feng-Hai, Z. Yan, and Y. Fan, "Research on deformation prediction method of soft soil deep foundation pit," Journal of Coal Science and Engineering, vol. 14, no. 4, pp. 637-639, 2008.

[9] X. K. Bao and M. H. Que, "A certain foundation pit support design and construction in baotou," Applied Mechanics and Materials, vol. 580-583, pp. 539-543, 2014.

[10] X. Y. Liu, W. P. Cai, J. Zhou, and X. Y. Wang, "Finite element study on ring-beam supporting structure of deep foundation pit in coastal soft soil area," Applied Mechanics and Materials, vol. 256-259, pp. 1908-1911, 2013.

[11] X. D. Zhang, Z. Liu, and X. J. Liu, "The stability analysis of deep foundation pit engineering support and field testing research," Applied Mechanics and Materials, vol. 105-107, pp. 1456-1459, 2012.

[12] Q. H. . Huang, "Geotechnical engineering practice of multiforms of composite support of deep foundation pit," Advanced Materials Research, vol. 838-841, pp. 690-696, 2014.

[13] H. Sun, Y. Chen, J. Zhang, and T. Kuang, "Analytical investigation of tunnel deformation caused by circular foundation pit excavation," Computers and Geotechnics, vol. 106, pp. 193-198, 2019.

[14] S. Chen, "Optimization of construction scheme of deep excavation pit adjacent to historic buildings," Underground Engineering and Tunnels, vol. 23, no. 3, pp. 20-22+51, 2015.

[15] R. Dan, M. Zhang, H. Zhou, N. Yang, and Z. Huang, "The theory and practice on deep excavation closing to ancient architectures," Construction \& Design for Project, vol. 40, no. 1, pp. 145-147, 2014.

[16] Y. Wang, "Monitoring of foundation ditch construction of the fujian market of wanmucaotang in guangzhou city," Mine Surveying, vol. 92, no. 2, pp. 29-31+78, 2006.

[17] National Standards of the People's Republic of China, Technical Specification for Retaining and Protection of Building Foundation Excavations(JGJ120-2012), pp. 16-28, China Construction Industry Press, China Academy of Building Sciences, Beijing, China, 2012.

[18] National Standards of the People's Republic of China, Technical Code for Building Pile Foundations(JGJ94-2008), China Academy of Building Sciences, Beijing, China, 1995.

[19] National Standards of the People's Republic of China, Code for Quality Acceptance of Building Foundation Engineering (GB50202-2002), China Academy of Building Sciences, Beijing, China, 2002.

[20] National Standards of the People's Republic of China, Code for Design of concrete Structures (GB50010-2002), China Academy of Building Sciences, Beijing, China, 2002.

[21] National Standards of the People's Republic of China, Technical Specifications for Foundation Pits Excavation for Buildings(YB9258-97), Metallurgical Industry Press, Beijing, China, 1997.

[22] National Standards of the People's Republic of China, Code for Investigation of Geotechnical Engineering(GB50021-2009), China Academy of Building Sciences, Beijing, China, 2009.
[23] National Standards of the People's Republic of China, Code for Design of Building Foundations(GB5007-2011), China Academy of Building Sciences, Beijing, China, 2011.

[24] C.-Y. Ou, J.-T. Liao, and W. Cheng, "Building response and ground movements induced by a deep excavation," Géotechnique, vol. 50, no. 3, pp. 209-220, 2000.

[25] Oucy, P. G. Hsieh, and Chioudc, "Characteristics of ground surface settlement during excavation," Canadian Geotechnical Journal, vol. 30, no. 5, pp. 758-767, 1993. 